\title{
MODULATION OF B-LYMPHOCYTES ACTIVITY BY CHOLINOTROPIC DRUGS BEFORE WATER-IMMERSION STRESS
}

\author{
G.I. Nezhinskaya, I.B. Krylova
}

Institute of Experimental Medicine, Saint Petersburg, Russia

\section{МОДУЛЯЦИЯ АКТИВНОСТИ В-ЛИМФОЦИТОВ ХОЛИНОТРОПНЫМИ ПРЕПАРАТАМИ ПЕРЕД ВОДНО-ИММЕРСИОННЫМ СТРЕССОМ}

\author{
Г.И. Нежинская, И.Б. Крылова \\ ФГБНУ «Институт экспериментальной медицины», Санкт-Петербург
}

irinakrylova@mail.ru

The aim of the work was to study the effect of modulation of B-lymphocytes activity with cholinotropic drugs on the stomach damage caused by water-immersion stress (WIS). The work was performed on male Wistar rats. Atropine $(2 \mathrm{mg} / \mathrm{kg})$, methacin $(2 \mathrm{mg} / \mathrm{kg})$ and choline alfoscerat $(90 \mathrm{mg} / \mathrm{kg})$ were administered 14 days before the WIS which lasted for 5 hours. The number of antibody-producing cells (APC) in spleen and the content of immunoglobulins $\operatorname{IgA}, \operatorname{IgG}, \operatorname{IgM}$ in blood were determined. The rats injected with saline were served as the control. On day 14 after administration of methacin or choline alfoscerat, but not atropine, an increase in the APC content in the spleen was observed comparing with control. At the same time, there was a significant decrease in the number of gastric ulcers. Thus on the model of water-immersion stress (WIS), it has been shown that B-lymphocytes can serve as a new target for the action of cholinotropic drugs, and modulation of their activity can provide effective prevention against stress.

Keywords: water-immersion stress; cholinotropic drugs; B-lymphocytes.

Целью работы явилось изучение влияния модулирования активности В-лимфоцитов холинотропными препаратами на повреждение желудка, вызванного воздействием водно-иммерсионного стресса (ВИС). Работа выполнена на крысах-самцах линии Вистар. Атропин (2 мг/кг), метацин (2 мг/кг) и холина альфосцерат (90 мг/кг) вводили за 14 суток до 5-часового ВИС. В селезенке определяли количество антител-образующих клеток (АОК), в крови - содержание иммуноглобулинов IgA, $\mathrm{IgG}$, IgM. Контролем служили крысы, которым вводили физиологический раствор. На 14 сутки после введения метацина или холина альфосцерата, но не атропина, наблюдалось увеличение содержания АОК в селезенке по сравнению с контролем. При этом происходило существенное снижение числа язв желудка, образующихся в результате ВИС. Таким образом, было показано, что В-лимфоциты являются новой мишенью действия холинотропных препаратов, а модуляция их активности может обеспечивать эффективную профилактику последствий стресса.

Ключевые слова: водно-иммерсионный стресс; холитропные препараты; В-лимфоциты.

Introduction. The development of water-immersion stress (WIS) is accompanied by domination of parasympathetic influences, which initiate ischemia and antioxidant stress of stomach [7]. Little attention has been paid to the modulation of the B-lymphocytes activity before the WIS to prevent its negative effects. Earlier we have shown that the use of B-lymphocyte stimulator 14 days before WIS and the stress protective agent 30 minutes before the WIS significantly limit the stomach damage [2]. In addition, it is known that agonists and antagonists of muscarinic and nicotinic acetylcholine receptors (m-, n-AChR) significantly enhance the antibody-producing activity of B-lymphocytes in spleen [3]. It can be assumed that the use of cholinotropic drugs may be an important direction in the development of rational approach to the prevention of the negative effects caused by different prolonged stresses. The aim of the work was to study the effect of B-lymphocytes modulation by cholinotropic drugs before WIS on the stomach damage.

Material and methods. The study was performed on Wistar male rats. The 5-hour WIS was modeled in rats after 24 hours hungry diet [7]. Antagonists of $\mathrm{m}-\mathrm{AchR}$ atropine $(2 \mathrm{mg} / \mathrm{kg})$ and metacin $(2 \mathrm{mg} / \mathrm{kg})$, and $\mathrm{m}-$ and $\mathrm{n}-\mathrm{AchR}$ agonist choline alfocerate $(90 \mathrm{mg} / \mathrm{kg})$ were administered 14 days before the WIS. The amount of antibody-producing cells (APC) was determined in the spleen [6]. In peripheral blood the content of immunoglobulins $\operatorname{IgA}, \operatorname{IgG}, \operatorname{IgM}$ were evaluated using commercial enzyme immunoassay kits. The rats treated with saline instead of drugs, were used as control.

Results and discussion. The obtained data showed that on the 14th day after the administration of metacin or choline alfoscerate, but not atro- 
The effect of cholinotropic agents on antibody production of B-lymphocytes and the number of ulcers in stomach of rats with WIS

\begin{tabular}{|l|c|c|c|c|c|}
\hline \multicolumn{1}{|c|}{ Drug } & APC/106 splenocytes & IgA (mg/ml) & IgG (mg/ml) & IgM (mg/ml) & $\begin{array}{c}\text { Index of gastric } \\
\text { damage, points }\end{array}$ \\
\hline Control & $486 \pm 40$ & $0.038 \pm 0.004$ & $0.497 \pm 0.005$ & $0.046 \pm 0.005$ & $3.2 \pm 0.2$ \\
\hline Atropine, $2 \mathrm{mg} / \mathrm{kg}$ & $510 \pm 45$ & $0.036 \pm 0.003$ & $0.503 \pm 0.011$ & $0.051 \pm 0.008$ & $2.5 \pm 0.3$ \\
\hline Metacin, $2 \mathrm{mg} / \mathrm{kg}$ & $2300 \pm 34^{*}$ & $0.031 \pm 0.002$ & $0.495 \pm 0.004$ & $0.054 \pm 0.012$ & $1.1 \pm 0.2^{*}$ \\
\hline $\begin{array}{l}\text { Choline alfocerate, } \\
80 \mathrm{mg} / \mathrm{kg}\end{array}$ & $1900 \pm 42^{*}$ & $0.036 \pm 0.002$ & $0.500 \pm 0.006$ & $0.049 \pm 0.004$ & $1.3 \pm 0.1^{*}$ \\
\hline
\end{tabular}

N o t e. ${ }^{*} p<0.001,8$ rats in group were used for each test.

pine, a high content of APC was determined in the spleen of experimental rats, but the concentrations of $\operatorname{IgA}, \operatorname{IgG}, \operatorname{IgM}$ did not differ from the control. A significant decrease in the number of ulcers in the stomach of these rats was observed (see Table).

We suggest that the most significant adaptive processes occur in the spleen and that the prolonged response of B-lymphocytes may be associated with the action of drug metabolites. It is known that metacin is a benzyl acid-choline ester [1]. Our previous studies of metacin metabolites identifica- tion showed that its disintegration leads to the formation of pharmacologically inactive 2-hydroxy-2, 2-diphenylacetic acid and pharmacologically active choline [5]. The drug choline alfoscerate splits into glycerophosphate and choline. Choline is an agonist of all AChR cell subtypes [1], and apparently can provide a prolonged effect of the drugs.

Conclusion. Thus B-lymphocytes can serve as a new target for the action of cholinotropic drugs, and modulation of their activity can provide effective prevention against stress.

\section{References}

1. Mashkovsky MD. Pharmaceuticals. Moscow: Novaya Volna; 2007. 1206 p.

2. Nezhinskaya GI, Petrova NN. The role of B-lymphocyte stimulation in the prevention of stress-induced gastric ulcers in Wistar rats. Cytokines and inflammation. 2006;(1):34-36.

3. Nezhinskaya GI, Losev NA, Sapronov NS. Effects of cholinergic antagonists under stress. Pat. Fiziol. Experiment. Ter. 2007;(2):12-13.

4. Nezhinskaya GI, Vladykin AL, Sapronov NS. Non-neuronal effects of a muscarinic antagonist in the prevention of stress. Experimental. Clinical Pharmacol. 2008;71(3):46-48.

5. Sapronov NS, Nezhinskaya GI, Vladykin AL. The role of metabolites of the muscarinic antagonist metacin in the regulation of inflammation. Med. Academ. J. 2009;9(1):28-32.

6. White KL, Musgrove DL, Brown RD. The sheep erythrocyte T-dependent antibody response (TDAR). Methods Mol. Biol. 2010;598:173-184.

7. Xie Y-F, Jiao Q, Guo Sh, et al. Role of parasympathetic overactivity in water immersion stress-induced gastric mucosal lesion in rat. J. Appl. Physiol. 2005;99:2416-2422. 